Research paper

\title{
Geochemistry and origin of organic-rich sediment veins in fractured granitic basement, Helmsdale, Sutherlandshire, UK
}

\author{
John Parnell*, Mas'ud Baba, Stephen Bowden, Liam Bullock \\ School of Geosciences, University of Aberdeen, Aberdeen AB24 3UE, UK
}

\section{A R T I C L E I N F O}

\section{Article history:}

Received 25 May 2017

Received in revised form

7 August 2017

Accepted 9 August 2017

Available online 12 August 2017

\section{Keywords:}

Injectites

Moray Firth

Helmsdale Fault

Helmsdale Granite

Great Glen Fault

\begin{abstract}
A B S T R A C T
Black sediment veins up to $2 \mathrm{~cm}$ width penetrate the Caledonian Helmsdale Granite in the vicinity of the Helmsdale Fault, onshore Moray Firth. The black colour and geochemistry of the veins reflect a high content of organic carbon. Both Devonian and Jurassic shales are conceivable available sources, but sterane compositions relate the organic matter to the Jurassic shales. A content of extractable organic matter higher than in the shales suggests that the carbon in the veins represents oil rather than mechanically mobilized shale. The oil was present during sediment vein emplacement. The veins were emplaced forcefully, which may reflect high fluid pressure associated with post-Jurassic movement on the Helmsdale Fault.
\end{abstract}

(C) 2017 The Authors. Published by Elsevier Ltd. This is an open access article under the CC BY license (http://creativecommons.org/licenses/by/4.0/).

\section{Introduction}

The veining of granitic basement rocks by sediments, especially sandstones, is well documented (Bouillin and Bellomo, 1990; Bouillin et al., 1997; Katzung and Obst, 1997; Siddoway and Gehrels, 2014). In most cases the veins appear to be passive infillings of brittle fractures in extensional settings, classically described as 'neptunean dykes'. Along the Helmsdale Fault, Sutherlandshire, UK, black sediment veins in the Caledonian Helmsdale Granite were noted briefly by Bailey and Weir (1932). Despite intense geological study of this region on the onshore margin of the hydrocarbon-bearing Moray Firth Basin (extensive literature reviewed in Macdonald and Trewin, 1993; Cox, 2001; Trewin and Hurst, 2009; McArthur et al., 2013), the age and significance of these veins have been unexplored. We use a combination of petrographic, organic biomarker and sulphur isotope analyses to characterize the type and source of the organic matter in the veins, and assess the mechanism and timing of their emplacement.

\section{Geological setting}

The coastal outcrops at the north western margin of the Moray

\footnotetext{
* Corresponding author.

E-mail address: J.Parnell@abdn.ac.uk (J. Parnell).
}

Firth expose the Devonian Helmsdale Granite, Devonian sediments and Jurassic sediments, the latter including the much-studied Helmsdale Boulder Beds (Fig. 1). These rocks lie adjacent to the Helmsdale Fault (Figs. 1 and 2), a splay off the Great Glen Fault. The Helmsdale Granite was exhumed rapidly after emplacement, and weathered to form a regolithic surface that passes almost imperceptibly upwards into a veneer of coarse Devonian sediment composed of granitic detritus. To the north of Helmsdale in Caithness and to the south in Ross-shire a more extensive Devonian sequence includes lacustrine rocks, some with hydrocarbon source rock potential. The granite and Devonian rocks are separated by the Helmsdale Fault from a Jurassic marine succession that includes sandstones, mudrocks with source rock potential, and boulder beds interpreted to represent submarine sliding during active faulting (Menzies and Whiteman, 2009; McArthur et al., 2013). The Jurassic boulder beds include clasts of Devonian lacustrine rock, interpreted to indicate Devonian source rocks deposited nearby but since removed by erosion (Marshall, 1998). Thus, both Devonian and Jurassic sedimentary successions are plausible origins for hydrocarbons in the region. This is reflected in the attribution of regional hydrocarbon shows to alternatively Devonian (Marshall, 1998) or Jurassic (Underhill, 1991) sources, based on different interpretations of burial history, or to a mixture of both sources based on biomarker evidence (Peters et al., 1989, 1999).

Veined granitic basement is exposed in the footwall of the fault on the foreshore to the north of the mouth of the Allt Briste, a 

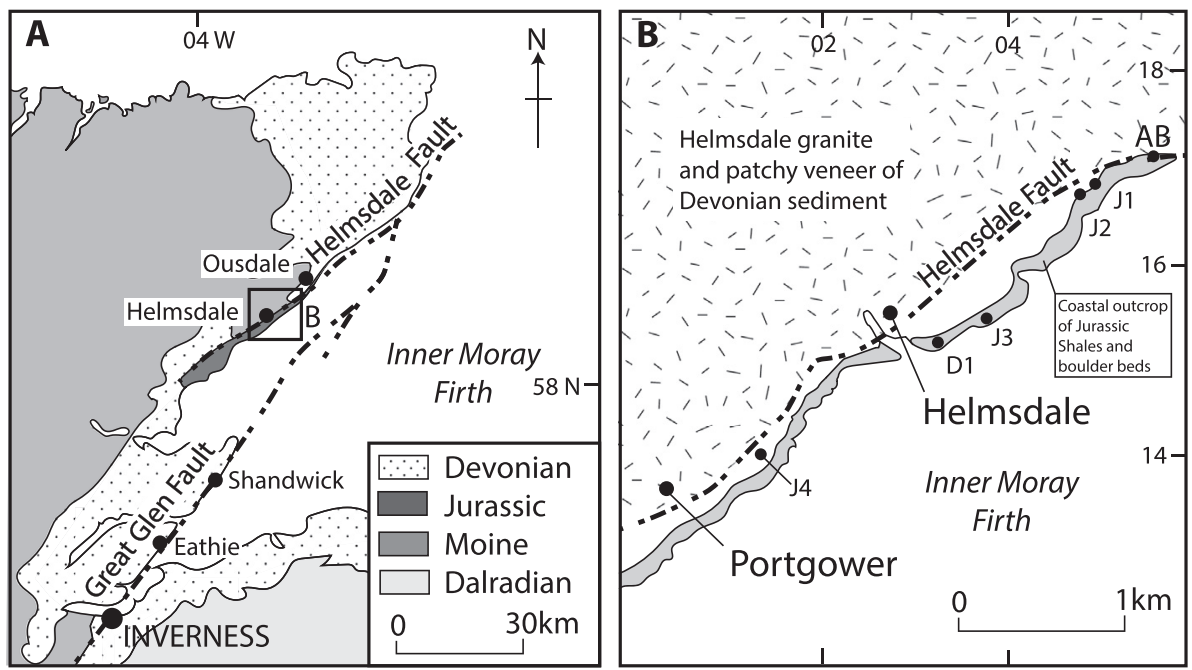

Fig. 1. Simplified maps of (A) regional geology in northern Scotland, and (B) Jurassic outcrop near Helmsdale, and location of veined granite at Allt Briste and shale samples. Granite intrusions omitted from map A for clarity. Minor Jurassic outcrops occur at Eathie and Shandwick. Detailed map after Wignall and Pickering (1993) and Cox (2001). National Grid Reference co-ordinates shown in map B. AB indicates Allt Briste locality.

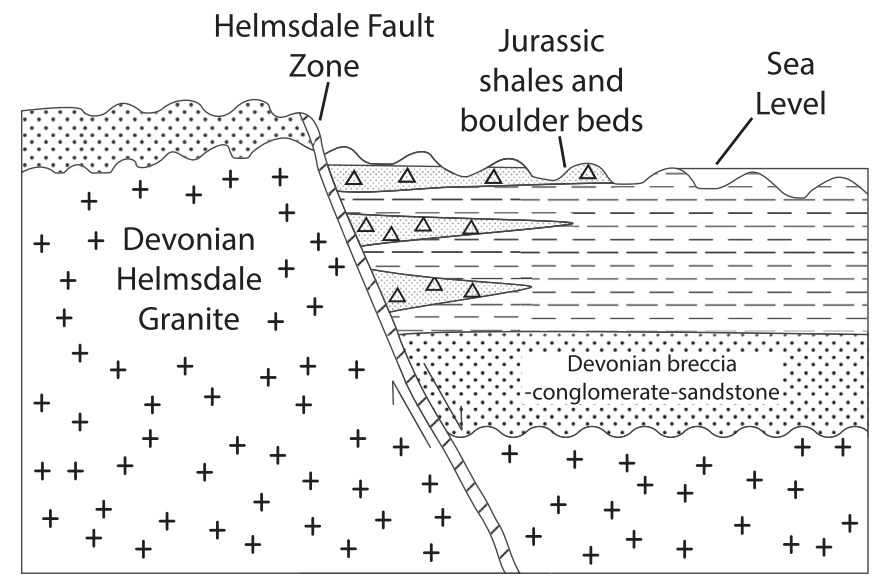

Fig. 2. Schematic cross-section through Helmsdale Fault Zone in vicinity of Helmsdale (after Peters et al., 1999). Organic matter was sampled in Jurassic shales, and clasts of Devonian shales in the Jurassic boulder beds.

stream draining off the Helmsdale Granite. Bailey and Weir (1932) reported both white and black sediment veins, and that the black veins cross-cut the white veins, but gave no further pertinent details. The granite is overlain unconformably by a variable thickness of up to $\sim 10 \mathrm{~m}$ of breccia-conglomerate-sandstone of assumed Devonian age (Fig. 2). Across the Helmsdale Fault over $10 \mathrm{~m}$ of Jurassic sediment youngs seawards. The fault zone is intensely fractured, sheared and veined with siliceous and calcareous sediment (Macdonald and Trewin, 1993). The structural geology of this portion of the fault zone is described by Thomson and Underhill (1993).

The regional occurrences of hydrocarbon source rocks and oil shows in sedimentary rocks (Trewin, 1989; Marshall, 1998; Marshall and Hewett, 2003; Peters et al., 1999; Ghazwani et al., 2017) raise the possibility that the black veins are hydrocarbonbearing. This study assesses:

(i) Whether the veins contain an oil residue, or mobilized organic-rich shale;

(ii) Whether any organic matter can be attributed to a Devonian or Jurassic source; (iii) Evidence for the mechanism of emplacement of the veins.

\section{Methodology}

Four sandstone veins (Fig. 3) were sampled (AB1 to AB4) from the Helmsdale Granite and Devonian breccia in the footwall of the Helmsdale Fault $200 \mathrm{~m}$ north of the mouth of the Allt Briste (National Grid Reference ND 052171), and subject to petrographic study, organic biomarker analysis and sulphur isotope analysis. For comparison, samples of shale were analysed for biomarkers, from four Jurassic exposures in the Helmsdale district (J1 to J4, Fig. 1) and from Devonian clasts in the Helmsdale Boulder Beds at Helmsdale Harbour (D1, Fig. 1). Petrographic studies allow assessment of the mechanism of emplacement of the veins, while biomarker analysis constrains the thermal maturity and source of the organic matter.

Petrographic studies of bituminous rocks were made using an ISIS ABT-55 scanning electron microscope with Link Analytical 10/ 55S EDAX facility.

Rock samples were prepared by rinsing with distilled water two times, and again with dichloromethane (DCM). The dry rocks were crushed and extracted using a soxhlet apparatus for $48 \mathrm{~h}$. Solid bitumen and tar samples were ultrasonicated with DCM and methanol $(\mathrm{MeOH})$. All glassware was thoroughly cleaned with a 93:7 mixture of DCM/MeOH. Crushed samples were weighed, recorded and transferred into pre-extracted thimbles. The extracts were then dried down using a rotary evaporator, separated into aliphatic, aromatic and polar fractions via a silica column chromatography using hexane, hexane/DCM in the ratio 3:1 and DCM/ $\mathrm{MeOH}$ respectively. Prior to gas chromatography-mass spectrometry (GC-MS) analysis, an internal standard ( $5 \beta$-Cholane, Agilent Technologies) was added to the saturate fraction before injection into the GC-MS machine, and subsequent biomarker identification. This was done using an Agilent 6890N gas chromatograph fitted with a J\&W DB-5 phase $50 \mathrm{~m}$ MSD and a quadruple mass spectrometer operating in SIM mode (dwell time $0.1 \mathrm{~s}$ per ion and ionisation energy $70 \mathrm{eV}$ ). Samples were injected manually using a split/splitless injector operating in splitless mode (purge $40 \mathrm{ml}$ min-1 for $2 \mathrm{~min}$ ). The temperature programme for the GC oven was $80-295^{\circ} \mathrm{C}$, holding at $80^{\circ} \mathrm{C}$ for $2 \mathrm{~min}$, rising to $10^{\circ} \mathrm{C}$ min- 1 for $8 \mathrm{~min}$ and then $3{ }^{\circ} \mathrm{C}$ min- 1 , and finally holding the maximum temperature 

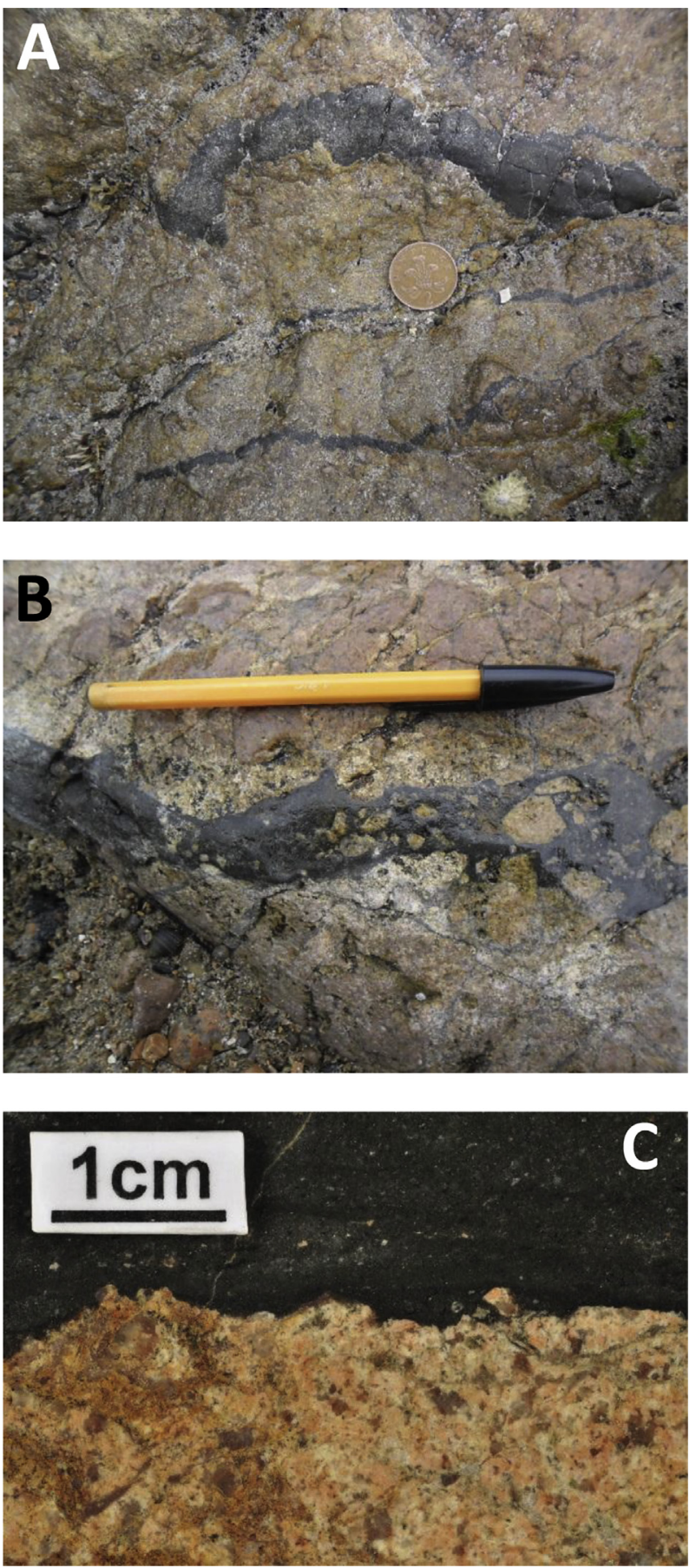

Fig. 3. Black veins at Allt Briste, cutting Helmsdale Granite. A, Array of veins, showing highly irregular margins; B, Vein showing incorporation of clasts of wallrock granite; C, Detail of vein margin, showing irregular nature.

for 10 min-1. Quantitative biomarker data were obtained for isoprenoids, hopanes, steranes and diasteranes by measuring responses of these compounds on $\mathrm{m} / \mathrm{z} 85,125,191,217,218$, and 259 mass chromatograms and comparing them to the response of the internal standard. Diasteranes are formed by a rearrangement of steranes during diagenesis and thermal maturation. Biodegradation causes the breakdown of steranes at a faster rate than diasteranes, including in the shallow subsurface in aerobic conditions, thus the diasterane/sterane ratio $(D / S)$ can be used as a measure of shallow biodegradation (Seifert and Moldowan, 1979). Evidence for biodegradation was also sought in 25-norhopanes, which form near the oil-water contact (Bennett et al., 2006) and have been recorded to be abundant in organic matter from veins in basement rocks elsewhere (Parnell et al., 2017). Thermal maturity was estimated from the $20 S / 20 S+20 R$ ratio for $C_{29}$ steranes, based on the increasing proportion of the $S$ isomer with maturation (Peters and Moldowan, 1993).

Pyrite separates were then analysed by standard techniques (Robinson and Kusakabe, 1975). 5-10 mg was utilised for isotopic analysis. $\mathrm{SO}_{2}$ gas was liberated by combusting the sulphides with excess $\mathrm{Cu}_{2} \mathrm{O}$ at $1075^{\circ} \mathrm{C}$, in vacuo. Liberated gases were analysed on a VG Isotech SIRA II mass spectrometer, and standard corrections applied to raw $\delta^{66} \mathrm{SO}_{2}$ values to produce true $\delta^{34} \mathrm{~S}$. All $\mathrm{SO}_{2}$ gases were analysed on a VG Isotech SIRA II mass spectrometer. The standards employed were NBS-123 and IAEA-S-3, and SUERC standard CP-1. These gave $\delta^{34} \mathrm{~S}$ values of $+17.1 \%$, $-31.6 \%$ and $-4.6 \%$ respectively, with $1 \sigma$ reproducibility better than $\pm 0.2 \%$ around the time of these analyses. Data are reported in $\delta^{34} S$ notation as per mil (\%o) variations from the Vienna Canyon Diablo Troilite (V-CDT) standard.

\section{Results}

\subsection{Field and petrographic observations}

Both black and white sediment veins occur up to $10 \mathrm{~cm}$ width. They cross-cut both granitic breccia (of assumed Devonian age) and solid granite (Fig. 3) but were not observed cutting Jurassic sediments. The veins penetrate in multiple orientations, they are filled to their tips, and they show spalling of wall rock from fresh (unweathered) fracture walls. The black veins are composed of siltstone and fine sandstone, while the white veins consist of fine to coarse sandstone. In rare cases where their relationship can be discerned, the black veins cut the white veins. The veins show no sense of shear, and do not appear to have been injected into a preexisting fracture system as they do not show transition into unfilled fractures. Exposures of the Devonian sediment-granite unconformity $1.5 \mathrm{~km}$ distant from the fault at Ousdale (ND 065197) show a regolithic surface mineralized by fluorite, but no veining (Gallagher et al., 1971).

Examination of several vein samples through granite and breccia, by scanning electron microscopy, show masses of solid carbonaceous material, some of which have associated abundant pyrite (Fig. 4).

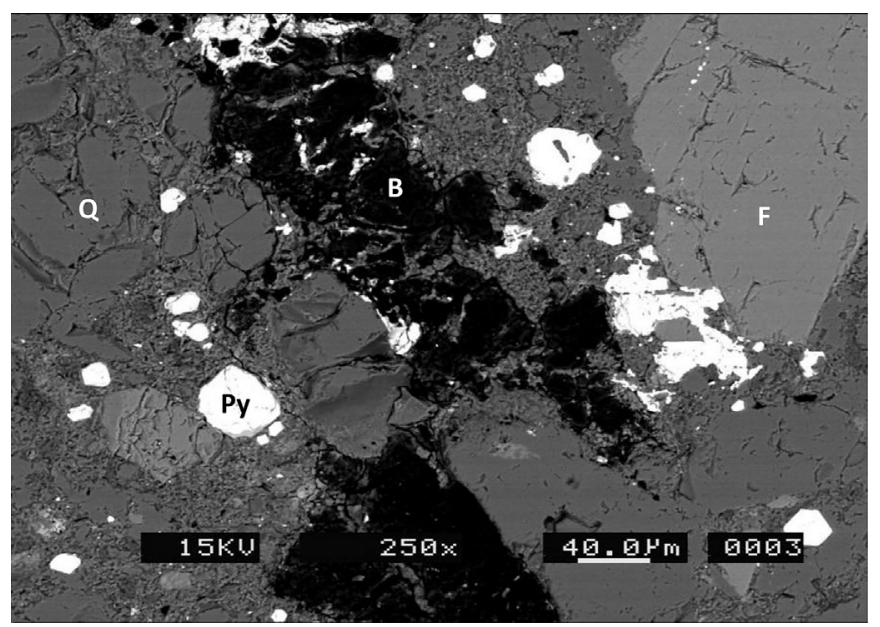

Fig. 4. Scanning electron micrograph of vein through granite (sample AB1), showing bitumen (B) and pyrite (Py), in country rock quartz (Q) and feldspar (F), Allt Briste. 


\subsection{Biomarkers}

All of the samples yielded extractable organic matter (EOM), from which biomarkers were determined. The amounts of EOM, per unit mass of organic carbon, are higher in the vein samples than in most of the Jurassic or Devonian shale samples (Table 1). A Single Jurassic sample also has a high EOM value.

Distributions of $n$-alkanes (Fig. 5) show that Jurassic samples exhibit a marked odd/even preference, and that Devonian samples contain a marked $\beta$-carotane peak that is absent from the other samples. The profiles for the vein samples exhibit a limited 'hump', characteristic of an unresolved complex mixture.

The relative proportions of $\mathrm{C}_{27}, \mathrm{C}_{28}$ and $\mathrm{C}_{29}$ steranes were determined from $\mathrm{m} / \mathrm{z} 217$ chromatograms (Table 1; Figs. 6 and 7). The Devonian clasts plot distinct from the other samples as they have relatively high contents of the $\mathrm{C}_{28}$ sterane. Ratios of diasteranes/steranes are in the range $0.17-0.47$ with higher values for veins compared to Jurassic shale samples.

The sterane $\mathrm{C}_{29} \alpha \alpha 20 \mathrm{~S} /(20 \mathrm{~S}+20 \mathrm{R})$ values, representing thermal maturity, are in the range $0.18-0.23$ for the Jurassic shales, 0.45 to 0.69 for the Devonian shales, and 0.14 to 0.49 for the veins.

No 25-norhopanes were recorded in any sample.

\subsection{Sulphur isotopes}

Two samples of pyrite from the margins of veins through the breccia yielded sulphur isotope compositions of +14.3 and $+4.1 \%$. Pyrite crystals in veins through the granite were too small for analysis. Two samples of pyrite from the Jurassic boulder beds at Helmsdale yielded values of -23.0 and $-24.0 \%$.

\section{Discussion}

\subsection{Organic matter in veins}

The black veins are coloured by organic matter, and have organic carbon contents up to $0.3 \%$ (Table 1 ). The organic matter could simply represent mobilised organic-rich shales, or alternatively could represent entrained hydrocarbons. Shale may be emplaced as dykes, especially within fault zones (e.g. Morley et al., 1998). These two possibilities can be distinguished using petrographic and chemical evidence. The masses of carbonaceous matter, without entrained silicates or other minerals (Fig. 4), suggest bitumen (solid oil residues). The higher amounts of EOM per unit mass organic carbon (Fig. 8) further indicate that the organic matter is a migrated product (i.e. oil) rather than physically mobilized kerogen. The single example of a Jurassic shale sample with high EOM value probably reflects traces of oil pooled on a bedding surface.

\subsection{Source of oil}

The Devonian samples exhibit a marked $\beta$-carotane peak (Fig. 5). This compound is typical of lacustrine sediments, and is recorded in previous analyses of Orcadian Basin Devonian samples (Irwin and Meyer, 1990; Othman Wilson et al., 2014). The peak is absent from the Jurassic shales and the vein samples, indicating that the Devonian is not the source of the organic matter in the veins, but the Jurassic could be the source.

The ternary plot of the relative proportions of the $C_{27}, C_{28}$ and $\mathrm{C}_{29} \alpha \alpha \alpha \mathrm{R}$ steranes is especially informative (Fig. 7). The Devonian samples distinctively contain a higher proportion of the $\mathrm{C}_{28}$ sterane, which is typical of the lacustrine depositional environment. The Jurassic marine shales contain less of the $C_{28}$ sterane. The Allt Briste vein samples all plot within the data field of the Jurassic samples.

The diasterane/sterane ratios for the veins are higher than the ratios for the Jurassic shale samples. These values suggest that the oil may have experienced limited biodegradation, during residence in a shallow reservoir. Limited 'humps' in the $n$-alkane chromatograms for the vein samples may also indicate minor biodegradation. The lack of 25-norhopanes is consistent with only minor biodegradation, and there is no evidence for the extensive biodegradation found in bitumen in some fractured basement (Marynowski et al., 2006; Parnell et al., 2017).

The higher sterane $C_{29} \alpha \alpha 20 S /(20 S+20 R)$ values for the Devonian shale clasts indicate that the organic matter in the clasts is more thermally mature than that in the Jurassic shales and the

Table 1

Biomarker data for samples of Veins through granite and Breccia, Jurassic shales, and Devonian clasts in Jurassic, Helmsdale district.

\begin{tabular}{|c|c|c|c|c|c|c|c|c|c|c|c|c|c|c|c|}
\hline Location & Grid Ref & Sample & $\begin{array}{l}\text { TOC } \\
(\%)\end{array}$ & $\begin{array}{l}\text { EOM } \\
(\%) \\
\end{array}$ & $\begin{array}{l}\text { EOM/ } \\
\text { TOC }\end{array}$ & $\begin{array}{l}\text { C29 D (mg/ } \\
\text { gE) }\end{array}$ & $\begin{array}{l}\text { C29 S (mg/ } \\
\mathrm{gE})\end{array}$ & $\mathrm{D} / \mathrm{S}$ & $\begin{array}{l}\operatorname{Pr}(\mathrm{mg} / \\
\mathrm{gE})\end{array}$ & $\begin{array}{l}\mathrm{Ph}(\mathrm{mg} / \\
\mathrm{gE})\end{array}$ & $\begin{array}{l}\mathrm{Pr} / \\
\mathrm{Ph}\end{array}$ & $\begin{array}{l}\text { C29 20S/ } \\
(20 S+20 R)\end{array}$ & $\begin{array}{l}\text { C27 S } \\
(\%) \\
\end{array}$ & $\begin{array}{l}\text { C28 S } \\
(\%) \\
\end{array}$ & $\begin{array}{l}\text { C29 S } \\
(\%)\end{array}$ \\
\hline $\begin{array}{l}\text { Allt Briste } \\
\text { AB1 }\end{array}$ & $\begin{array}{l}\text { ND } \\
052171\end{array}$ & $\begin{array}{l}\text { Vein in } \\
\text { granite }\end{array}$ & 0.28 & 4.06 & 14.5 & 0.006 & 0.02 & 0.29 & 0.35 & 0.7 & 0.51 & 0.49 & 54 & 12 & 34 \\
\hline $\begin{array}{l}\text { Allt Briste } \\
\text { AB2 }\end{array}$ & $\begin{array}{l}\text { ND } \\
052171\end{array}$ & $\begin{array}{l}\text { Vein in } \\
\text { granite }\end{array}$ & 0.19 & 1.55 & 8.16 & 0.003 & 0.01 & 0.47 & 0.13 & 0.3 & 0.4 & 0.07 & 41 & 14 & 45 \\
\hline $\begin{array}{l}\text { Allt Briste } \\
\text { AB3 }\end{array}$ & $\begin{array}{l}\text { ND } \\
052171\end{array}$ & $\begin{array}{l}\text { Vein in } \\
\text { breccia }\end{array}$ & 0.29 & 2.7 & 9.31 & 0.003 & 0.01 & 0.23 & 0.40 & 0.6 & 0.72 & 0.15 & 31 & 15 & 54 \\
\hline $\begin{array}{l}\text { Allt Briste } \\
\text { AB4 }\end{array}$ & $\begin{array}{l}\text { ND } \\
052171\end{array}$ & $\begin{array}{l}\text { Vein in } \\
\text { breccia }\end{array}$ & 0.21 & 1.9 & 9.05 & 0.004 & 0.01 & 0.33 & 1.20 & 1.8 & 0.68 & 0.23 & 44 & 12 & 44 \\
\hline $\begin{array}{l}\text { Helmsdale } \\
\text { D1A }\end{array}$ & $\begin{array}{l}\text { ND } \\
033152\end{array}$ & $\begin{array}{l}\text { Devonian } \\
\text { Clast }\end{array}$ & 1.44 & 1.14 & 0.79 & 0.15 & 0.48 & 0.32 & 1.65 & 2.1 & 0.8 & 0.69 & 24 & 40 & 36 \\
\hline $\begin{array}{l}\text { Helmsdale } \\
\text { D1B }\end{array}$ & $\begin{array}{l}\text { ND } \\
033152\end{array}$ & $\begin{array}{l}\text { Devonian } \\
\text { Clast }\end{array}$ & 1.41 & 3.96 & 2.81 & 0.18 & 0.53 & 0.34 & 2.01 & 2.3 & 0.9 & 0.69 & 21 & 41 & 38 \\
\hline $\begin{array}{l}\text { Helmsdale } \\
\text { D1C }\end{array}$ & $\begin{array}{l}\text { ND } \\
033152\end{array}$ & $\begin{array}{l}\text { Devonian } \\
\text { Clast }\end{array}$ & 1.29 & 1.42 & 1.1 & 0.07 & 0.40 & 0.17 & 8.97 & 9.2 & 0.97 & 0.45 & 12 & 56 & 32 \\
\hline $\begin{array}{l}\text { Helmsdale } \\
\text { J1 }\end{array}$ & $\begin{array}{l}\text { ND } \\
047165\end{array}$ & $\begin{array}{l}\text { Jurassic } \\
\text { Shale }\end{array}$ & 1.29 & 10.9 & 8.5 & 99.08 & 540.20 & 0.18 & 1175.45 & 3818.9 & 0.3 & 0.22 & 23 & 22 & 55 \\
\hline $\begin{array}{l}\text { Helmsdale } \\
\text { J2 }\end{array}$ & $\begin{array}{l}\text { ND } \\
045162\end{array}$ & $\begin{array}{l}\text { Jurassic } \\
\text { Shale }\end{array}$ & 2.53 & 4.85 & 1.92 & 0.21 & 1.25 & 0.17 & 1.54 & 4.8 & 0.3 & 0.22 & 24 & 23 & 53 \\
\hline $\begin{array}{l}\text { Helmsdale } \\
\text { J3A }\end{array}$ & $\begin{array}{l}\text { ND } \\
036154\end{array}$ & $\begin{array}{l}\text { Jurassic } \\
\text { Shale }\end{array}$ & 3.07 & 2.81 & 0.92 & 0.64 & 3.06 & 0.21 & 7.69 & 19.5 & 0.4 & 0.23 & 35 & 21 & 44 \\
\hline $\begin{array}{l}\text { Helmsdale } \\
\text { J3B }\end{array}$ & $\begin{array}{l}\text { ND } \\
036154\end{array}$ & $\begin{array}{l}\text { Jurassic } \\
\text { Shale }\end{array}$ & 2.62 & 3.57 & 1.36 & 0.04 & 0.21 & 0.19 & 0.60 & 1.5 & 0.4 & 0.18 & 17 & 24 & 59 \\
\hline Portgower & $\begin{array}{l}\text { ND } \\
014137\end{array}$ & $\begin{array}{l}\text { Jurassic } \\
\text { Shale }\end{array}$ & 6.02 & 1.09 & 0.18 & 0.49 & 2.69 & 0.18 & 81.55 & 65.3 & 1.2 & 0.21 & 30 & 16 & 54 \\
\hline
\end{tabular}




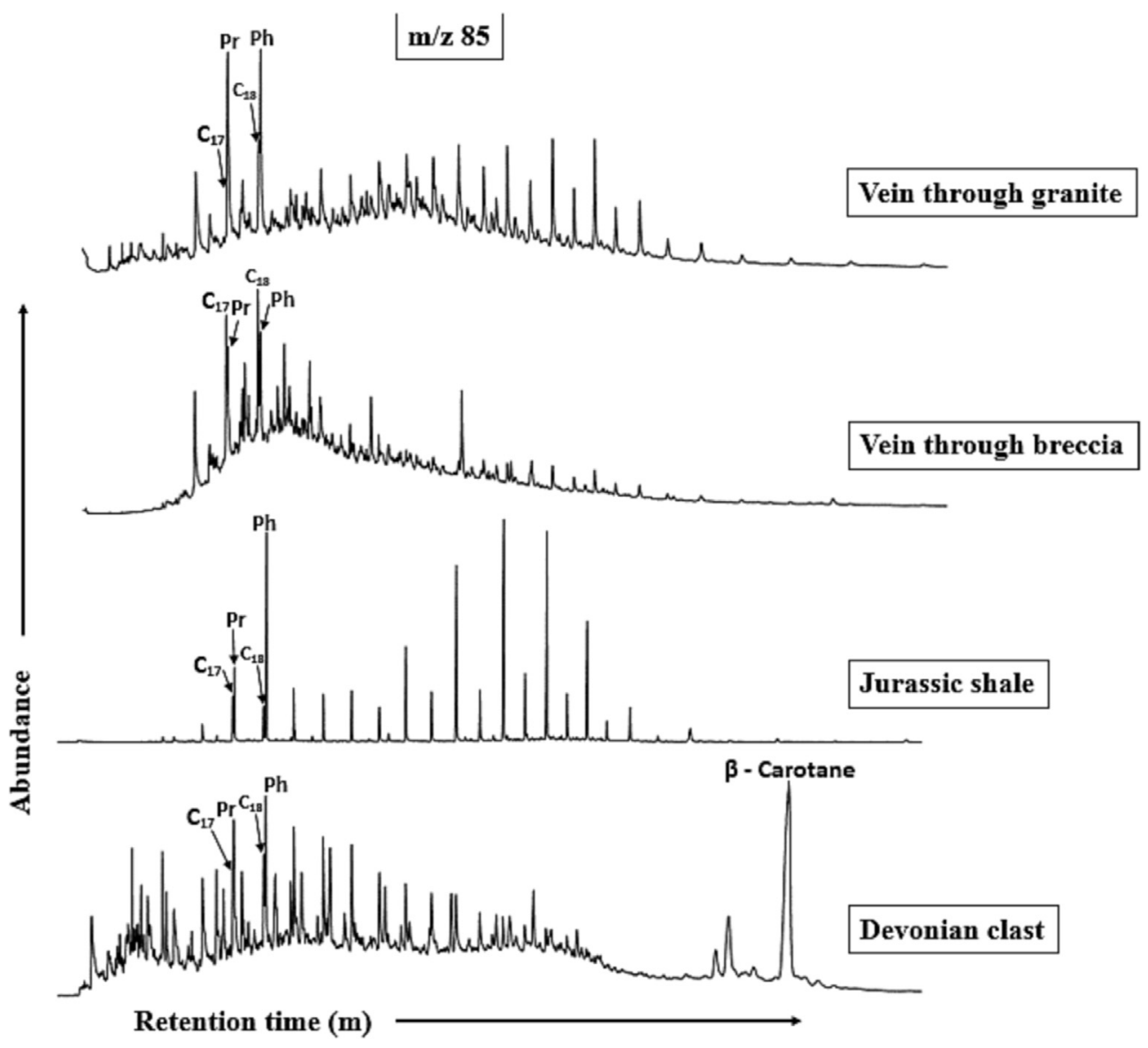

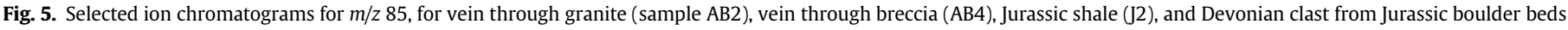

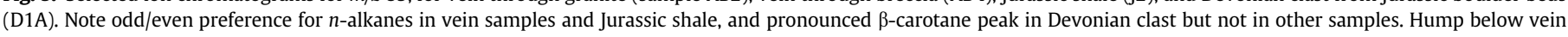
samples may reflect limited biodegradation.

veins. The difference in maturity is also evident from the $n$-alkane distributions (Fig. 5), which show an odd/even preference in the Jurassic, typical of immature sediments (Peters and Moldowan, 1993), but no preference in the Devonian samples, typical of mature sediments. Marshall (1998) demonstrated that oil emplacement in Devonian siltstone clasts occurred before incorporation into the boulder beds, implying a pre-Mesozoic phase of oil generation. This, and the apparently lithified state of the clasts when incorporated into the boulder beds, also indicates a higher maturity for the Devonian than in the Jurassic. This evidence further excludes the Devonian as a source of the organic matter in the veins. The comparable sterane $C_{29} \alpha \alpha 20 S /(20 S+20 R)$ value ranges for the Jurassic and vein samples is consistent with a Jurassic source for the veins.

\subsection{Vein emplacement}

Sandstone veins into older rocks could represent passive infilling of open joints and other fractures, especially at weathered unconformity surfaces, or forceful penetration under high fluid pressure (Jolly and Lonergan, 2002; Jonk et al., 2004). The petrography of the veins into the Helmsdale Granite, especially the filling to vein tips and spalling of fracture walls, suggests forceful penetration. Furthermore, the occurrence of bitumen (solid oil) in the sediment, and the cross-cutting of at least two vein generations, implies formation in the subsurface rather than at an exposed land surface. The Jurassic sediments in the vicinity of the Helmsdale
Fault-Great Glen Fault zone exhibit a range of sediment injection structures, most commonly involving the injection of sandstone into mudstone (Waterston, 1950; Jonk et al., 2003; Hurst et al., 2003). The injections occurred while the sediments were not completely consolidated, and are attributed to high fluid pressures triggered by movements in the fault zone. One possibility for the sandstone veins into the Helmsdale Granite is that they belong to the same family of sediment injections, although only the veins in the granite are dark-coloured, and this relationship is not consistent with the probable source of oil discussed below. Injected sands may become pathways for oil migration after emplacement (e.g. De Boer et al., 2007; Jonk et al., 2007), but there are examples where the injected sediment is already hydrocarbon-bearing (e.g. Jonk, 2010; Sherry et al., 2012). The fluidization of sand entrained in oil may occur much more readily than sand entrained in water (Jonk, 2010), so the oil may have been critical to formation of the veins at Allt Briste. The development of high pore fluid pressure during oil generation could also contribute to the fracturing of the granite, as found in several cases of oil/bitumen-bearing vein systems elsewhere (Parnell et al., 1994; Parnell and Carey, 1995). Although the veins may originate in the Jurassic, this does not necessarily mean that the entrained oil is of Jurassic origin. The oil could be of Devonian age, generated during Mesozoic burial or generated earlier and re-migrated during fault movements. However the age of the source rock can be resolved through biomarker distributions.

Given a Jurassic source, the close proximity to the Helmsdale Fault could reflect sediment injection during active movement on 


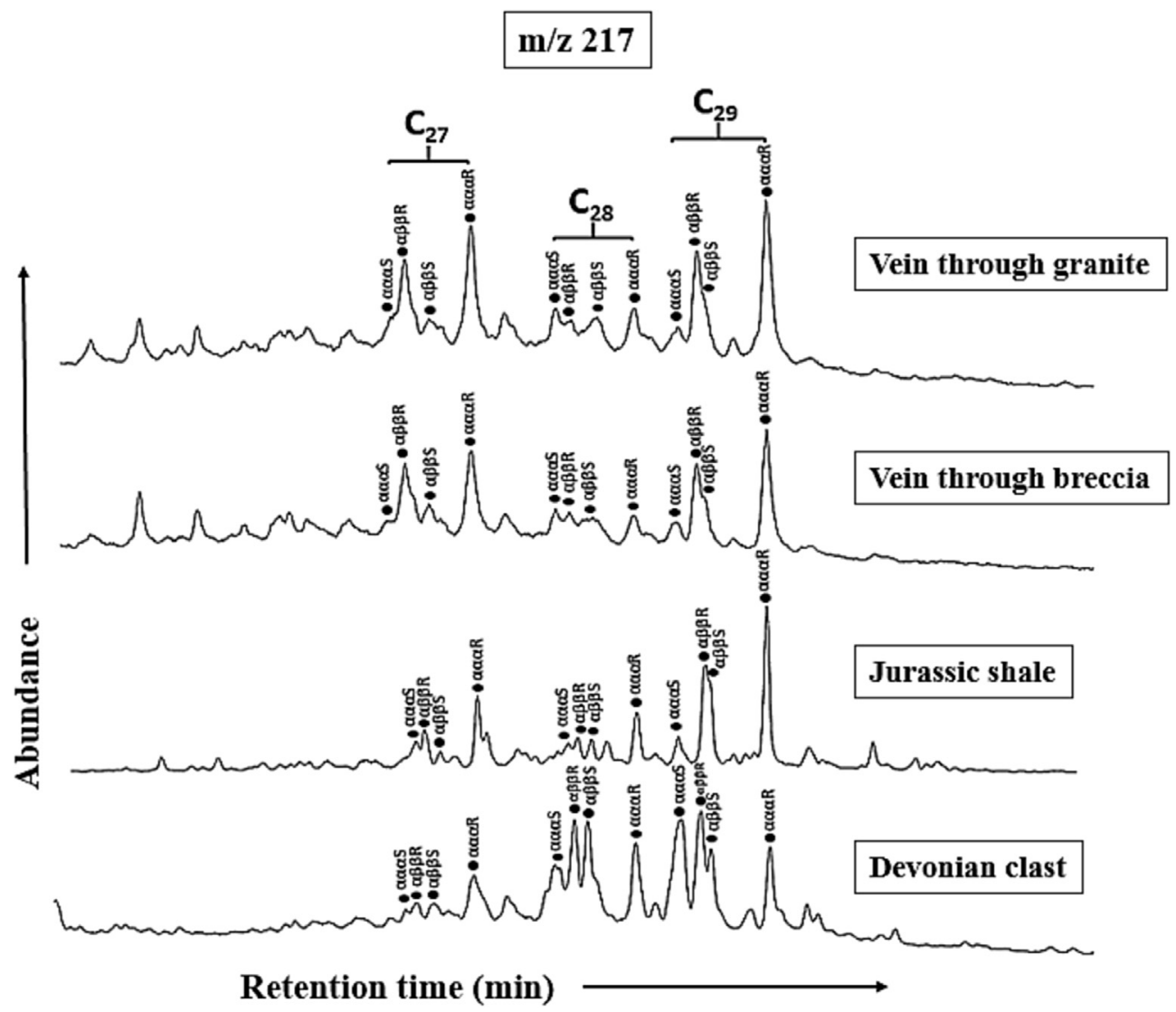

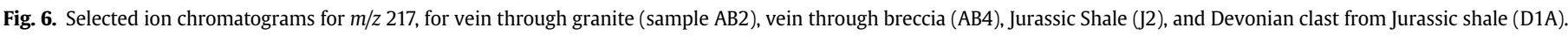

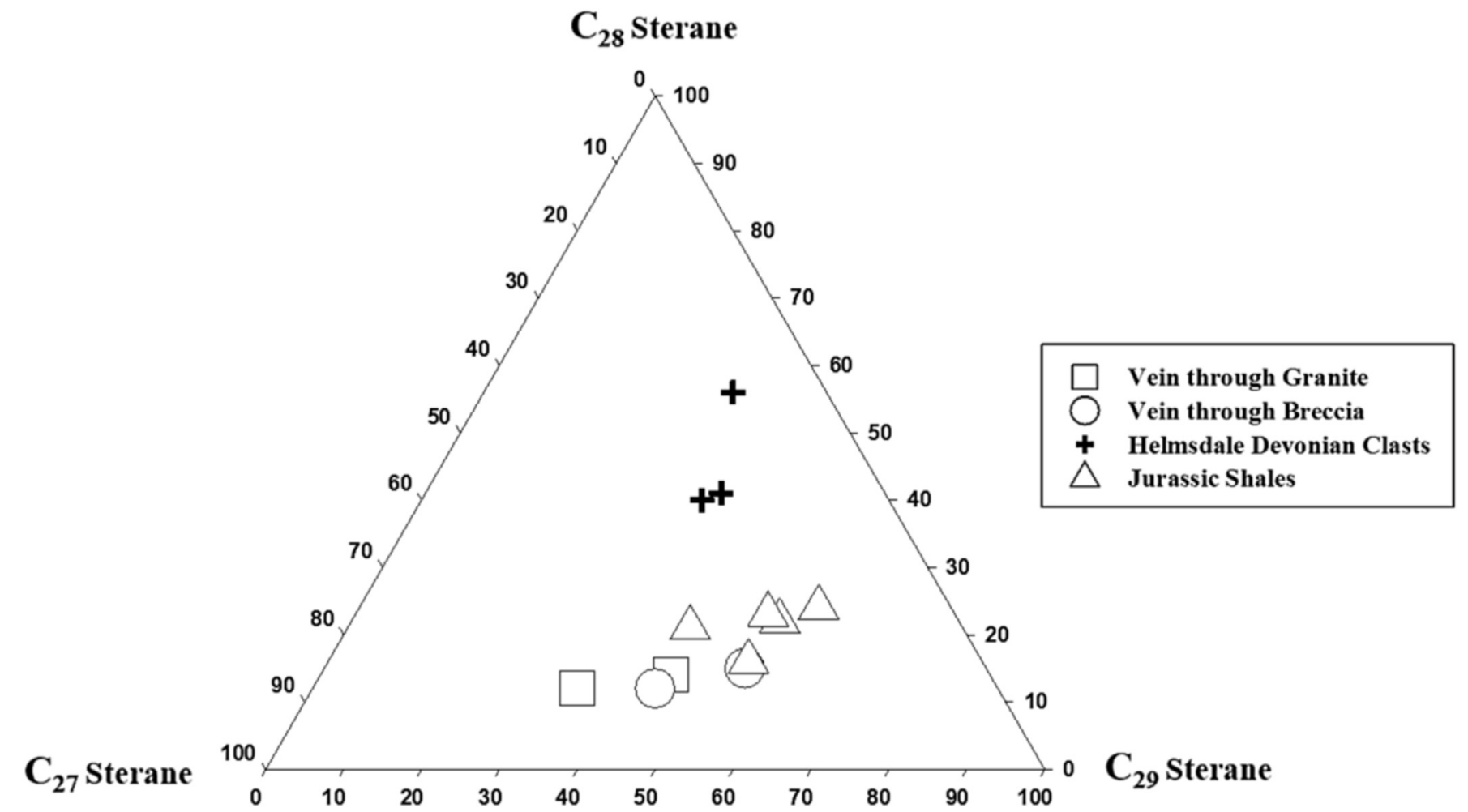

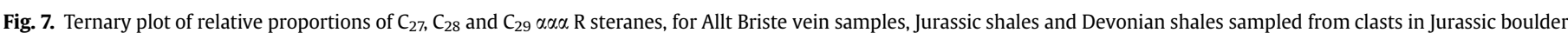

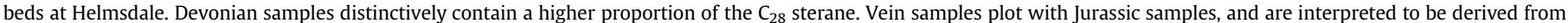
Jurassic sediments. 


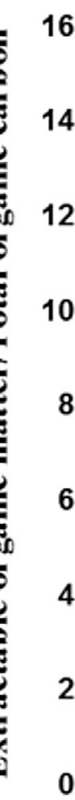

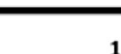

1

\section{西}
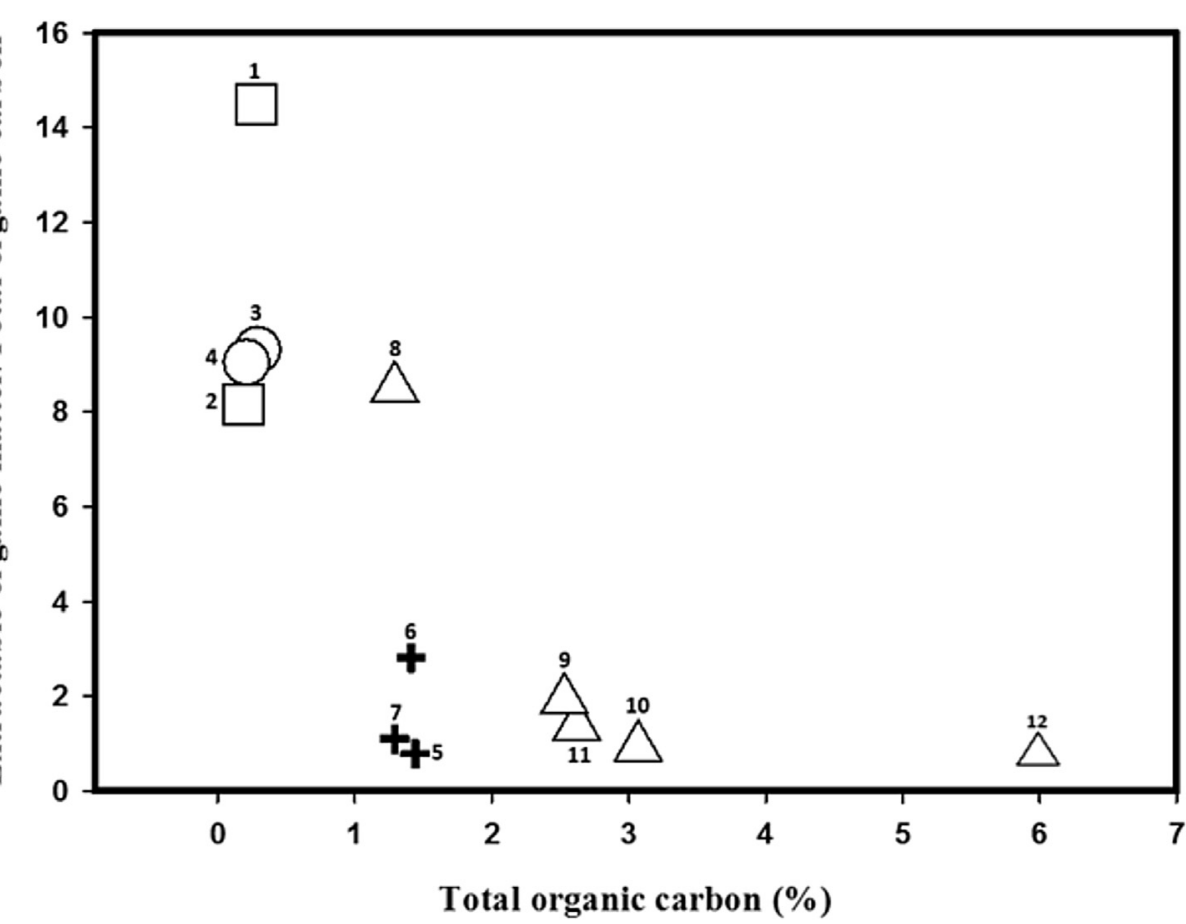

\section{SAMPLES}

Vein through granite (Allt Briste ND 052171) ${ }^{1}$

Vein through granite (Allt Briste ND 052171) ${ }^{2}$

Vein through breccia (Allt Briste ND 052171) ${ }^{3}$

Vein through breccia (Allt Briste ND 052171) 4

+ Helmsdale D1A (ND 033152) 5

+ Helmsdale D1B (ND 033152) $^{6}$

+ Helmsdale D1C (ND 033152) 7

$\triangle$ Helmsdale J1 (ND 047165) 8

$\triangle$ Helmsdale J2 (ND 045162) ${ }^{9}$

$\triangle$ Helmsdale J3A (ND 036154) 10

$\triangle$ Helmsdale J3B (ND 036154) 11

$\triangle$ Portgower J4 (ND 014137) 12

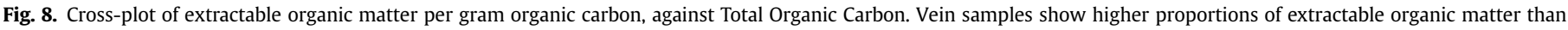
most shale samples, indicating generated oil. A single Jurassic shale sample also may contain generated oil.

the Helmsdale Fault and Great Glen Fault during the Jurassic (Wignall and Pickering, 1993; Thiérault and Steel, 1995; McArthur et al., 2013) or later fault motion that has juxtaposed Jurassic marine shales against granite (Le Breton et al., 2013). Two lines of evidence indicate a post-Jurassic timing. Firstly, oil in the veins with a Jurassic signature requires a timing during/after oil generation from the Jurassic shales. Maturation of the Late Jurassic shales is estimated to be mid-late Cretaceous in the Inner Moray Firth (Pearson and Duncan, 1996; Oakman and Partington, 1998). Secondly, if the veins were syn-sedimentary fault motion, when the boulder beds were deposited, we might expect some similarity in the composition of diagenetic pyrite in the boulder beds and in the veins. However, the two lots of pyrite have compositions separated by $27-38 \%$. Despite the limited data base, this difference strongly suggests that the sulphur in the two settings was derived from a different source. A post-Jurassic timing suggests that the veins are probably younger than the other sediment injections in the vicinity of the Helmsdale Fault-Great Glen Fault zone, as the latter injections formed while the Jurassic sediments were incompletely consolidated and thus not at the stage of oil generation. The Helmsdale Granite is cross-cut by extensive fractures that may be related to un-roofing of the granite in the early Devonian (Gallagher et al., 1971; Tweedie, 1979). These early fractures are tightly sealed, and cross-cut by the sediment veins. Fracturing of Permian age, containing oil residues of Devonian-sourced oil, occur in north Caithness (Dichiarente et al., 2016), and are probably related to extension offshore in the West Orkney Basin. Both of these fracture systems pre-date a Jurassic oil source, and although they could conceivably be reactivated at a later stage, evidence for Jurassic and post-Jurassic movements and deformation on the Helmsdale FaultGreat Glen Fault system imply that there was adequate cause of new fracturing.

\section{Conclusions}

The petrographic, organic biomarker and sulphur isotope study of the granite-hosted black veins adjacent to the Helmsdale Fault Zone at Allt Briste has contributed to an understanding of their origin. In particular:

(i) The veins contain relatively high contents of extractable organic matter, and are thus concluded to contain migrated oil;

(ii) The organic matter in the veins has a biomarker composition consistent with derivation from the marine Jurassic shales exposed in the area, and unlike lacustrine Devonian shales exposed in the area, and thus they are attributed a Jurassic sourceThe organic matter in the veins has a thermal maturity compatible with a Jurassic source, rather than with a Devonian source;

(iii) Vein emplacement occurred forcefully, and was probably related to post-Jurassic movement along the Helmsdale Fault.

\section{Acknowledgements}

$\mathrm{MB}$ is in receipt of a PhD studentship from the Petroleum Technology Development Fund of Nigeria. LB is supported by NERC grant NE/M010953/1. C. Taylor, W. Ritchie and J. Johnston provided skilled technical support. Sulphur isotope measurements were made at SUERC. The manuscript benefitted substantially from the careful reviews of A.G. Leslie and an anonymous referee.

\section{References}

Bailey, E.B., Weir, J., 1932. Submarine faulting in Kimmeridgian times, East Sutherland. Trans. R. Soc. Edinb. 57, 429-467.

Bennett, B., Fustic, M., Farrimond, P., Huang, H., Larter, S.R., 2006. 25-Norhopanes: formation during biodegradation of petroleum in the subsurface. Org. Geochem. 37, 787-797.

Bouillin, J.-P., Bellomo, 1990. The Jurassic neptunian dykes of Longobucco-Caloveto (Italy); their use for analysis of the paleostructures of a Tethyan margin. Geodin. Acta 4, 111-120.

Bouillin, J.-P., Pecher, A., Rolland, Y., Carrio, E., Dumont, T., Tricart, P., 1997. Jurassic 
neptunian dykes of Mount Pelvoux as recorders of Apline deformations at the eastern border of the Oisans massif, western Alps. Comptes Rendus de l'Académie des Sci. Ser. 2. Sci. de la Terre des Planètes 324, 409-415.

Cox, B.M., 2001. Helmsdale. In: Wright, J.K., Cox, G.M. (Eds.), British Upper Jurassic Stratigraphy (Oxfordian to Kimmeridgian). Geological Conservation Review Series, vol. 21. Joint Nature Conservation Committee, Peterborough.

De Boer, W., Rawlinson, P.B., Hurst, A., 2007. Successful exploration of a sand injectite complex: hamsun prospect, Norway Block 24/9. In: Hurst, A., Cartwright, J. (Eds.), Sand Injectites: Implications for Hydrocarbon Exploration and Production, pp. 65-68. AAPG Memoir, 87.

Dichiarente, A.M., Holdsworth, R.E., Dempsey, E.D., Selby, D., McCaffrey, K.J.W., Michie, U. McL., Morgan, G., Bonniface, J., 2016. New structural and Re-Os geochronological evidence constraining the age of faulting and associated mineralization in the Devonian Orcadian Basin, Scotland. J. Geol. Soc. Lond. 173, 457-473.

Gallagher, M.J., Michie, U. McL., Smith, R.T., Haynes, L., 1971. New evidence of uranium mineralization in Scotland. Trans. Inst. Min. Metall. 80, B150-B173.

Ghazwani, A., Littke, R., Sachse, V., Fink, R., Mahlstedt, N., Hartkopf-Fröder, C., 2017. Organic geochemistry, petrology and palynofacies of Middle Devonian lacustrine flagstones in the Orcadian Basin, Scotland: depositional environment, thermal history and petroleum generation potential. Geol. Mag. http:// dx.doi.org/10.1017/S0016756816000984.

Hurst, A., Cartwright, J., Duranti, D., 2003. Fluidization structures produced by upward injection of sand through a sealing lithology. Geol. Soc. Lond. Spec. Publ. 216, 123-137.

Irwin, H., Meyer, T., 1990. Lacustrine organic facies. A biomarker study using multivariate statistical analysis. Org. Geochem. 16, 197-210.

Jolly, R.J.H., Lonergan, L., 2002. Mechanisms and controls of the formation of sand intrusions. J. Geol. Soc. Lond. 159, 605-617.

Jonk, R., 2010. Sand-rich injectites in the context of short-lived and long-lived fluid flow. Basin Res. 22, 603-621.

Jonk, R., Duranti, D., Hurst, A., Parnell, J., Fallick, A.E., 2007. Aqueous and petroleum fluids associated with sand injectites hosted by lacustrine shales from the oilshale group (Dinantian), Midland Valley, Scotland. In: Hurst, A., Cartwright, J. (Eds.), Sand Injectites: Implications for Hydrocarbon Exploration and Production, pp. 265-274. AAPG Memoir, 87.

Jonk, R., Duranti, D., Parnell, J., Hurst, A., Fallick, A.E., 2003. The structural and diagenetic evolution of injected sandstones: examples from the Kimmeridgian of NE Scotland. J. Geol. Soc. Lond. 160, 881-894.

Jonk, R., Kelly, J., Parnell, J., 2004. The origin and tectonic significance of Lewisianand Torridonian-hosted clastic dykes near Gairloch, NW Scotland. Scott. J. Geol. 40, 123-130.

Katzung, G., Obst, K., 1997. The sandstone dyke swarm of Vang, Bornholm (Denmark). Bull. Geol. Soc. Den. 44, 161-171.

Le Breton, E., Cobbold, P.R., Zanella, A., 2013. Cenozoic reactivation of the Great Glen Fault, Scotland: additional evidence and possible causes. J. Geol. Soc. Lond. 170, 403-415.

Macdonald, A.C., Trewin, N.H., 1993. The upper Jurassic of the Helmsdale area. In: Trewin, N.H., Hurst, A. (Eds.), Excursion Guide to the Geology of East Sutherland and Caithness. Scottish Academic Press, Edinburgh, pp. 75-114.

Marshall, J.E.A., 1998. The recognition of multiple hydrocarbon generation episodes: an example from Devonian lacustrine sedimentary rocks in the Inner Moray Firth, Scotland. J. Geol. Soc. Lond. 155, 335-352.

Marshall, J.E.A., Hewett, A.J., 2003. Devonian. In: Evans, D., Graham, C., Armour, A., Bathurst, P. (Eds.), The Millennium Atlas: Petroleum Geology of the Central and Northern North Sea. The Geological Society of London, London, pp. 65-81.

Marynowski, L., Gawęda, A., Poprawa, P., Zywiecki, M.M., Kępińska, B., Merta, H., 2006. Origin of organic matter from tectonic zones in the Western Tatra Mountains Crystalline Basement, Poland: an example of bitumen-source correlation. Mar. Petrol. Geol. 23, 261-279.

McArthur, A.D., Hartley, A.J., Jolley, D.W., 2013. Stratigraphic development of an Upper Jurassic deep marine syn-rift succession, Inner Moray Firth Bain, Scotland. Basin Res. 25, 285-309.

Menzies, J., Whiteman, C., 2009. A comparative analysis of microstructures from Late Jurassic diamictic units, near Helmsdale, northeast Scotland and a
Pleistocene diamicton from near Milton, southern Ontario, Canada - a differential diagnostic method of sediment typing using micromorphology. Neth. J. Geosci. 88, 75-94.

Morley, C.K., Crevello, P., Ahmad, Z.H., 1998. Shale tectonics and deformation associated with active diapirism: the Jerudong Anticline, Brunei Darussalam. J. Geol. Soc. Lond. 155, 475-490.

Oakman, C.D., Partington, M.A., 1998. Cretaceous. In: Glennie, K.W. (Ed.), Petroleum Geology of the North Sea: Basin Concepts and Recent Advances, fourth ed. Blackwell Science, London, pp. 294-349.

Othman Wilson, A., Parnell, J., Boyce, A.J., Bowden, S.A., 2014. Constraining causes of fish mass mortality using ultra-high-resolution biomarker measurement. Chem. Geol. 385, 156-162.

Parnell, J., Baba, M., Bowden, S., Muirhead, D., 2017. Subsurface biodegradation of crude oil in a fractured basement reservoir, Shropshire, UK. J. Geol. Soc. Lond. $174,655-666$.

Parnell, J., Carey, P., 1995. Emplacement of bitumen (asphaltite) veins in the Neuquen Basin, Argentina. Am. Assoc. Petrol. Geol. Bull. 79, 1798-1816.

Parnell, J., Geng, A., Fu, J., Sheng, G., 1994. Geology and geochemistry of bitumen vein deposits at Ghost City, Junggar Basin, northwest China. Geol. Mag. 131, 181-190.

Pearson, M.J., Duncan, A.D., 1996. Biomarker maturity profiles in the Inner Moray Firth Basin and implications for inversion estimates. In: Hurst, A. (Ed.), Geology of the Humber Group: Central Graben and Moray Firth, UKCS, vol. 114. Geological Society Special Publication, pp. 287-298.

Peters, K.E., Clutson, M.J., Robertson, G., 1999. Mixed marine and lacustrine input to an oil-cemented sandstone breccia from Brora, Scotland. Org. Geochem. 30, 237-248.

Peters, K.E., Moldowan, J.M., 1993. The Biomarker Guide: Interpreting Molecular Fossils in Petroleum and Ancient Sediments. Prentice Hall, Englewood Cliffs, NJ.

Peters, K.E., Moldowan, J.M., Driscole, A.R., Demaison, G.J., 1989. Origin of Beatrice oil by co-sourcing from devonian and middle Jurassic source rocks, Inner Moray Firth, United Kingdom. Am. Assoc. Petrol. Geol. Bull. 73, 454-471.

Robinson, B.W., Kusakabe, M., 1975. Quantitative preparation of sulfur dioxide for 34S/32S analyses from sulphides by combustion with cuprous oxide. Anal. Chem. 47, 1179-1181.

Seifert, W.K., Moldowan, J.M., 1979. The effect of biodegradation on steranes and terpanes in crude oils. Geochim. Cosmochim. Acta 43, 111-126.

Sherry, T.J., Rowe, C.D., Kirkpatrick, J.D., Brodsky, E.E., 2012. Emplacement and dewatering of the world's largest exposed sand injectite complex. Geochem. Geophys. Geosys. 13, Q08008. http://dx.doi.org/10.1029/2012GC004157.

Siddoway, C.S., Gehrels, G.E., 2014. Basement-hosted sandstone injectites of Colorado: a vestige of the Neoproterozoic revealed through detrital zircon provenance analysis. Lithosphere 6, 403-408.

Thiérault, P. Steel, RJ. 1995. Syn-rift sedimentation in the upper Jurassic (Helmsdale boulder beds) of the Inner Moray Firth. In: Steel, R.J., Felt, V.L, Johannessen, E.P., Mathieu, C. (Eds.), Sequence Stratigraphy on the Northwes European Margin, vol. 5. Norwegian Petroleum Society Special Publication, pp. 365-387.

Thomson, K., Underhill, J.R., 1993. Controls on the development and evolution of structural styles in the Inner Moray Firth Basin. In: Parker, J.R. (Ed.), Petroleum Geology of Northwest Europe: Proceedings of the 4th Conference. The Geological Society, London, pp. 1167-1178.

Trewin, N.H., 1989. The petroleum potential of the old red sandstone of northern Scotland. Scott. J. Geol. 25, 201-225.

Trewin, N.H., Hurst, A., 2009. Excursion Guide to the Geology of East Sutherland and Caithness, second ed. Aberdeen Geological Society, Aberdeen.

Tweedie, J.R., 1979. Origin of uranium and other metal enrichments in the Helmsdale Granite, eastern Sutherland, Scotland. Trans. Inst. Min. Metall. 88 B145-B153.

Underhill, J.R., 1991. Implications of mesozoic-recent basin development in the western Inner Moray Firth. UK. Mar. Petrol. Geol. 8, 359-369.

Waterston, C.D., 1950. Note on the sandstone injections of Eathie Haven, Cromarty. Geol. Mag. 87, 133-139.

Wignall, P.B., Pickering, K.T., 1993. Palaeoecology and sedimentology across a Jurassic fault scarp, NE Scotland. J. Geol. Soc. Lond. 150, 323-340. 